\title{
THE BRYOPHYTE DIVERSITY OF CENTRAL PARK (ARCHBISHOP'S GARDEN) OF EGER TOWN (HUNGARY)
}

\author{
Péter Szúcs ${ }^{1 *}$, Gabriella Fintha ${ }^{1}$ \& Gergö Fazekas ${ }^{2}$
}

\begin{abstract}
${ }^{1}$ Eszterházy Károly University, Institute of Biology, Department of Botany and Plant Physiology, H-3300 Eger, Leányka u. 6, Hungary; ${ }^{2}$ Eszterházy Károly University, $H$ 3300 Eger, Leányka u. 6, Hungary; *E-mail: szucs.peter@uni-eszterhazy.hu
\end{abstract}

\begin{abstract}
The objective of the present work was the evaluation of the bryophyte diversity of the central park of Eger town. Altogether 59 taxa (4 liverworts and 55 mosses) were recorded. Nearly half of the identified species (49\%) belong to three families: Orthotrichaceae, Pottiaceae, and Brachytheciaceae. Brachythecium glareosum, Cirriphyllum piliferum, Eucladium verticillatum, Orthotrichum obtusifolium and Orthotrichum pumilum are rated near threatened (NT) according to the Hungarian Red List. Some of the taxa found in Eger were not known from other central east european urban parks (Ctenidium molluscum, Hygroamblystegium tenax, Pohlia melanodon, Cirriphyllum crassinervium, Hypnum cupressiforme var. lacunosum, Orthotrichum stramineum and Orthotrichum striatum). There are remarkable differences between central park of Eger and other Central and Eastern European parks regarding species composition and the percentage of species in each of the life strategy categories.
\end{abstract}

Keywords: downtown, urban area, Sørensen index, comparison

\section{INTRODUCTION}

There is growing recognition of urban areas as hosts for innovative ways to conserve and promote biodiversity. Parks, as one specific type of urban green space, constitute particularly important biodiversity hotspots in the cityscape (Nielsen et al. 2014).

In Central and Eastern Europe several publications address the bryophyte flora or diversity of parks and gardens in urban areas, for example Warsaw, Łódź and other Polish cities (Fudali 2006, Wolski et al. 2012), Lviv (Mamchur el al. 2018), Bucharest (Gomoiu and Ștefănuţ 2008), Vel'ký Krtíš (Mišíková et al. 2007), Sofia (Gospodinov et al. 2018) and Bratislava (Godovičová and Mišíková 
2017). The aim of this study was the examination of the bryophyte diversity of the central park of Eger town.

Knowledge about the bryophytes of anthropogenic habitats in Hungary is limited, and the following papers focus mostly on the description of floristic data: Budapest city (Szepesfalvi 1940, 1941, 1942) Barcs (Szűcs et al. 2014), the towns of Sopron (Szűcs 2015) and Gödöllő (Király et al. 2019). The bryophyte flora of Almásfüzitő (Szűcs et al. 2017a), Balaton village (Zsólyom and Szűcs 2018), and of the manor park of Martonvásár village (Nagy et al. 2016) are well documented in Hungary. However, there are no publications aiming at completeness with respect to the bryophyte diversity of parks of downtown areas in Hungary.

\section{MATERIALS AND METHODS}

Site details descriptions include data in the following order in the Appendix: habitat, GPS-coordinates, date of collection. Based on the Central European Flora Mapping System (Király et al. 2003), each collection point belongs to the 8188.1 square. The nomenclature follows Király (2009) for vascular plants, Söderström et al. (2016) for liverworts, and Hill et al. (2006) for mosses. In order to characterise the conservation and indicator status of taxa the Hungarian Red List was used (Papp et al. 2010). We used the Sørensen index (Sørensen 1948) for the comparison of the species composition of different localities. Collected specimens are deposited at the Cryptogamic Herbarium of the Department of Botany and Plant Physiology at the Eszterházy Károly University, Eger (EGR).

\section{Study area}

The town of Eger belongs to the Eger-Bükkalja micro-region, which is a colline area at an elevation of 126 to $420 \mathrm{~m}$ above sea level, slightly sloping to the south-east. The settlement is situated on the terraced valley of the Eger Creek, and to a smaller extent it covers the hillside accompanying the valley of the Tárkány Creek (Sugár 1983).

It is a region with a moderately warm to moderately dry climate. The average annual temperature is $9.0-10.0{ }^{\circ} \mathrm{C}$ at the highest points. The average annual precipitation is approximately $600 \mathrm{~mm}$, 
of which $340-380 \mathrm{~mm}$ is produced during the vegetation period. The likelihood of rainfall is the highest in early summer and late autumn (Dövényi 2010, Sugár 1983).

The dominance of the North-West winds is evident in every season, which is particularly characteristic during the summer months. In terms of wind flow speed, Eger is classified into the moderately windy areas of Hungary, which is also indicated by the relatively high frequency of wind silences (Dövényi 2010, Sugár 1983). The Eger Creek forms the boundary of the park in the northeast. The groundwater of the Eger valley has particularly hard water rich in sodium-calcium-hydrogencarbonate and sulfate (Sugár 1983).

The historical descriptions from the 15th and 16th century refer to this part of our town as a rich forested area where the wildlife park was located which was probably established by a bishop of Eger from the Renaissance. The former wildlife park was much larger than today's Archbishop's Garden. It included the area of today's Thermal bath, the present Archbishop's Garden, and also the Csákó district, which extends to the present railway station.

In the park there is an ornamental garden, on the left side of the creek there is a flower garden up to the mills, and between the mills and today's Csákány street there is a vegetable garden which together formed the old bishop's garden. The episcopal ornamental garden was established during the time of Ferenc Barkóczy (17101765), in the style of French gardens. In 1769 Bishop Károly Eszterházy (1725-1799) initiated the construction of a stone fence and ornate baroque gates to replace the old wooden fence. The oldest trees in the park are sycamore trees, estimated to be between 300 and 400 years old. Lajos Szmrecsányi (1851-1943) opened the gates of the 14-hectare Archbishop's Garden to the citizens of the town in 1919, and since then the area has been under significant human influence. (Herzegné Székely 2010). As for the park's maintenance, lawn mowing and leaf collection is performed regularly. 


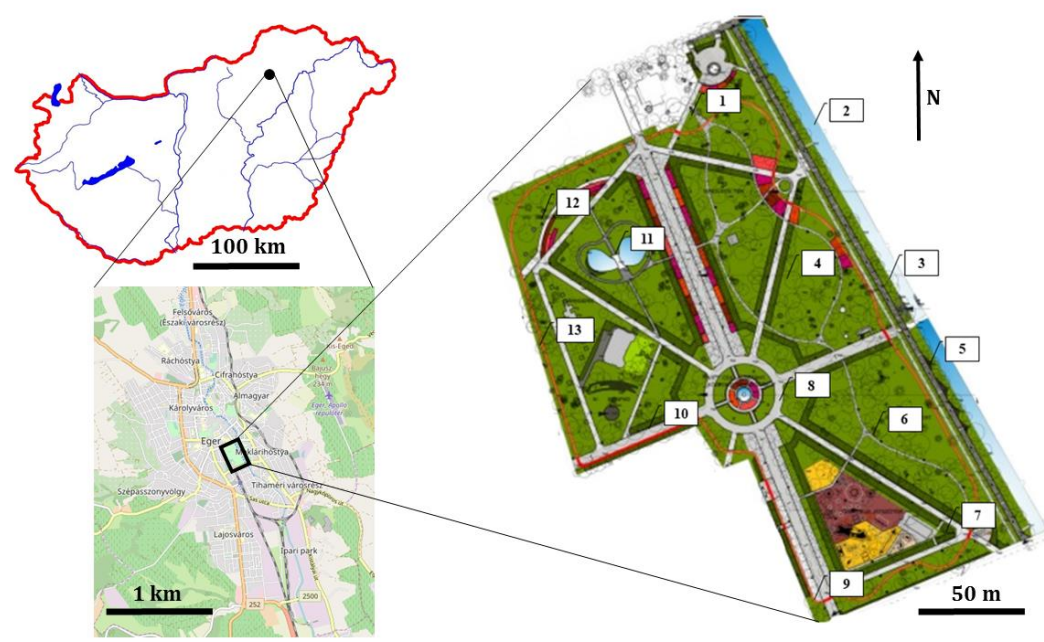

Figure 1. The situation of Eger town, and the map and collecting points of the central park of Eger.

\section{RESULTS AND DISCUSSION}

\section{List of species}

Numbers refer to sites (Figure 1) listed in the Appendix. The substrates given after a colon refer to all listed sites.

Marchantiophyta

Frullania dilatata (L.) Dumort. - LC - 1: bark of Fraxinus

Marchantia polymorpha subsp. ruderalis Bischl. \& Boisselier - LC - 3: rock in stream water

Pellia endiviifolia (Dicks.) Dumort. - LC - 2: rock in stream water Radula complanata (L.) Dumort. - LC - 1: bark of Sophora japonica; 6, 7: bark of Acer negundo; 5: bark of Ailanthus altissima

Bryophyta

Amblystegium serpens (Hedw.) Schimp. - LC - 1: artifical stone; 3 : wall of the stream; 4, 5: soil; 7, 12: concrete and mown lawn Atrichum undulatum (Hedw.) P. Beauv. - LC - 7, 9: shaded soil 
Barbula unguiculata Hedw. - LC - 1, 3, 13: shaded soil

Brachytheciastrum velutinum (Hedw.) Ignatov \& Huttenen - LC -

12: concrete

Brachythecium glareosum (Bruch ex Spruce) Schimp. - NT - 3: wall of the stream bank

Brachythecium rutabulum (Hedw.) Schimp. - LC - 1, 9: soil; 4, 5, 6: mown lawn; 10: stone fence; 11: artifical stone; 12: concrete; 13: andesit stone wall

Brachythecium salebrosum (F. Weber et D. Mohr) Schimp. - LC 5: bark of Ailanthus altissima

Bryoerythrophyllum recurvirostrum (Hedw.) P. C. Chen - LC-att 3: wall of the stream bank

Bryum argenteum Hedw. - LC - 1, 8, 11: artifical stone; 3: wall of the stream; 7, 8, 12: concrete; 10: stone fence

Bryum caespiticium Hedw. - LC - 1: concrete

Bryum capillare Hedw. - LC - 3: soil bank

Bryum moravicum Podp. - LC - 3: wall of stream bank, bark of Tilia platyphyllos; 13: andesit stone wall; 5: bark of Ailanthus altissima

Calliergonella cuspidata (Hedw.) Loeske - LC - 11: artifical stone; 13: andesite stone wall

Ceratodon purpureus (Hedw.) Brid. - LC - 3: wall of the stream bank; 7, 8,12: concrete; 8, 10: soil

Cirriphyllum crassinervium (Taylor) Loeske \& M. Fleisch - LC - 3: wall of stream bank

Cirriphyllum piliferum (Hedw.) Grout - NT - 1: soil

Cratoneuron filicinum (Hedw.) Spruce - LC - 2: rock in stream water

Ctenidium molluscum (Hedw.) Mitt. - LC - 5: rubble

Didymodon rigidulus Hedw. - LC-att - 7, 8: concrete; 10: stone fence

Eucladium verticillatum (With.) Bruch \& Schimp. - NT - 2: artifical stone in thermal water

Fissidens taxifolius Hedw. - LC - 5, 7, 9: shaded soil

Grimmia pulvinata (Hedw.) Sm. - LC - 1, 8: artifical stone; 7, 12: concrete; 13: andesite stone

Homalia trichomanoides (Hedw.) Brid. - LC-att - 5: rubble

Homalothecium lutescens (Hedw.) H. Rob. -LC - 4, 6: soil

Homalothecium sericeum (Hedw.) Schimp. LC - 3: wall of the stream bank, 13: andesite stone wall 
Homomallium incurvatum (Schrad. ex Brid.) Loeske - LC - 3: wall of the stream bank

Hygroamblystegium tenax (Hedw.) Jenn. - LC - 2: rock in stream

Hygroamblystegium varium (Hedw.) Mönk. - LC-att - 11: wet soil on lake shore

Hypnum cupressiforme Hedw.- LC - 1: artifical stone, bark of Fraxinus, and Sophora japonica 3: wall of the stream bank; 4, 5, 6, 7: soil; 13: andesite stone

Hypnum cupressiforme var. lacunosum Brid. - LC - 3: wall of the stream bank

Leskea polycarpa Ehrh. ex Hedw. - LC - 1: bark of Sophora japonica; 3, 4, 5, 6: bark of Acer negundo; 5: bark of Tilia platyphyllos

Leucodon sciuroides (Hedw.) Schwägr. - LC - 1: bark of Fraxinus

Orthotrichum affine Schrad. ex Brid. - LC - 1: bark of Fraxinus; and Sophora japonica; 4, 6: bark of Acer negundo; 5: bark of Tilia platyphyllos and Ailanthus altissima

Orthotrichum anomalum Hedw. - LC - 1: artifical stone; 3: wall of the stream bank; 13: andesite stone wall

Orthotrichum cupulatum Hoffm. ex Brid. - LC-att - 1: artifical stone; 3: wall of the stream bank

Orthotrichum diaphanum Schrad. ex Brid. - LC - 1, 4, 6: bark of Acer negundo

Orthotrichum obtusifolium Brid. - NT - 1: bark of Fraxinus; 4, 6: bark of Acer negundo; 10: bark of Sophoria japonica

Orthotrichum pallens Bruch ex Brid. - LC - 5, 7: bark of Tilia platyphyllos; 10: bark of Sophoria japonica

Orthotrichum pumilum Sw. ex anon. - NT - 10: stone fence

Orthotrichum speciosum Nees - LC-att - 5, 7: bark of Tilia platyphyllos

Orthotrichum stramineum Hornsch. ex Brid. - LC - 5, 7: bark of Tilia platyphyllos; 10: bark of Sophoria japonica

Orthotrichum striatum Hedw. - LC-att - 5, 7: bark of Tilia platyphyllos

Oxyrrhynchium hians (Hedw.) Loeske - LC - 1, 4, 5, 6, 7, 8, 12: soil

Plagiomnium cuspidatum (Hedw.) T. J. Kop. - LC - 3, 7, 9: soil

Plagiomnium undulatum (Hedw.) T. J. Kop. - LC - 7, 9: soil

Platygyrium repens (Brid.) Schimp. - LC - 5: artifical stone; 7, 8: concrete

Pohlia melanodon (Brid.) A.J. Shaw - LC - 3: soil of stream bank 
Pylaisia polyantha (Hedw.) Schimp. - LC - 1: bark of Fraxinus; 4, 6: bark of Acer negundo

Schistidium crassipilum H. H. Blom - LC - 1: artifical stone; 3: wall of the stream bank

Sciuro-hypnum populeum (Hedw.) Ignatov \& Huttunen - LC - 3: wall of the stream bank

Syntrichia papillosa (Wilson) Jur. - LC-att - 1: bark of Fraxinus

Syntrichia ruralis (Hedw.) F. Weber \& D. Mohr - LC - 3: wall of the stream bank

Syntrichia virescens (De Not.) Ochyra - LC-att - 1: bark of Fraxinus; 3: wall of the stream bank; 10: stone fence

Tortula muralis Hedw. - LC - 1, 8, 11: artifical stone; 7, 8, 12: concrete

Tortula truncata (Hedw.) Mitt. - LC - 7: soil

\section{Bryophyte diversity}

Altogether 59 bryophytes were detected in the central park of Eger, which include 4 liverworts (7\%) and 55 mosses (93\%). The liverwort species belong to 4 families and 4 genera, while the mosses belong to 16 families and 32 genera (Figure 2).

Nearly half of the species (49.15\%) belong to the 3 families Orthotrichaceae (10 taxa), Brachytheciaceae (10 taxa) and Pottiaceae (9 taxa).

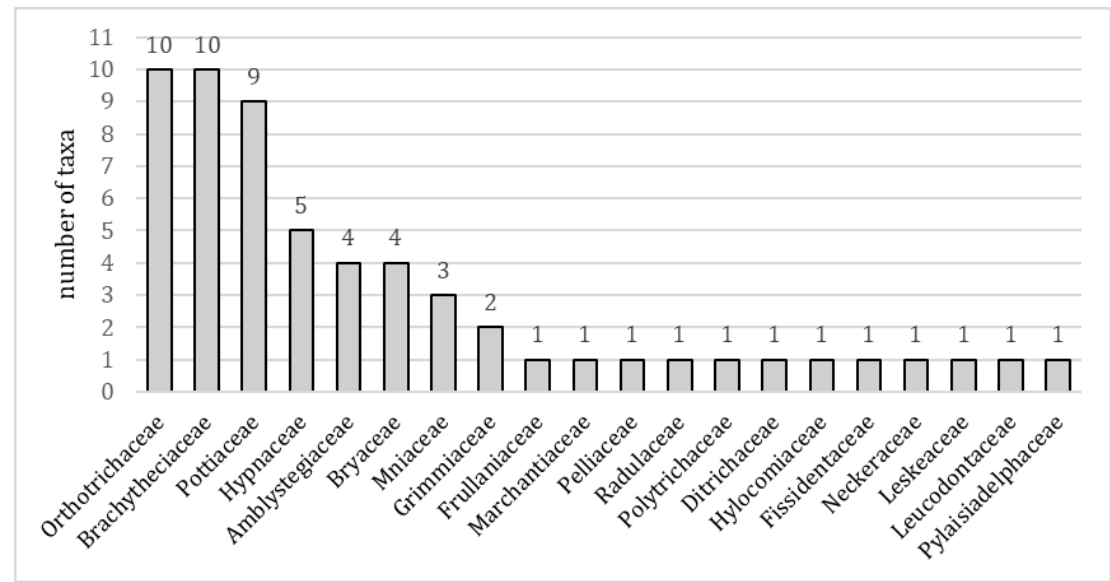

Figure 2. Distribution of bryophyte species found in the central park of the Eger town among families (Taxonomy follows Goffinet and Shaw 2009 and Söderström et al. 2016). 
Many of the common mosses of the central park of Eger, including Amblystegium serpens, Barbula unguiculata, Brachythecium rutabulum, B. salebrosum, Bryum argenteum, Ceratodon purpureus, Fissidens taxifolius, Grimmia pulvinata, Hypnum cupressiforme, Leskea polycarpa, Leucodon sciuroides, Orthotrichum affine, O. anomalum, O. diaphanum, O. pumilum, Oxyrrhynchium hians, Plagiomnium undulatum, Platygyrium repens, Pylaisia polyantha, Syntrichia ruralis and Tortula muralis have also been found in some other parks of Central East European settlements (Fudali 2006, Wolski et al. 2012, Mamchur el al. 2018, Gomoiu and Ștefănuț 2008, Mišíková et al. 2007, Gospodinov et al. 2018 and Godovičová and Mišíková 2017).

Atrichum undulatum and Homalia trichomanoides occur in some Central East European parks (Fudali 2006, Mamchur el al. 2018) and Eucladium verticillatum was detected in the forest park of Lviv city (Mamchur el al. 2018). These three species are not known from other hungarian settlements (Szű́cs et al. 2017a, Zsólyom and Szűcs 2018).

There are a few taxa in Eger, which are not known in the Central East European urban parks (Fudali 2006, Wolski et al. 2012, Mamchur et al. 2018, Gomoiu and Ștefănuţ 2008, Mišíková et al. 2007, Gospodinov et al. 2018 and Godovičová and Mišíková 2017), for example Ctenidium molluscum, Hygroamblystegium tenax, Pohlia melanodon, Cirriphyllum crassinervium, Hypnum cupressiforme var. lacunosum, Orthotrichum stramineum and O. striatum.

Table 1 shows the values of the Sørensen index, which are derived from a comparison of moss species in the region, in Central and Eastern European parks, and the central park of Eger. The values of parks in Central and Eastern Europe are similar in this respect, there is no notable difference between the calculated data (0.415-0.590). Compared to the park of Eger, the discrepancy is most pronounced in the case of the Teaching Garden, Łódź (0.415). The Botanical Garden or EKU is situated closest to the central park of Eger and shows the greates similarity in species composition (highest Sørensen index of 0.590). 
Table 1. Comparison of the area, the distance of localities from Eger, the altitude, the number of taxa and Sørensen index of central east european parks with central park of Eger town.

\begin{tabular}{|c|c|c|c|c|c|}
\hline Name of locality & $\begin{array}{c}\text { area } \\
\text { (hectare) }\end{array}$ & $\begin{array}{c}\text { distance } \\
\text { from } \\
\text { Central } \\
\text { park of } \\
\text { Eger }(\mathbf{k m})\end{array}$ & $\begin{array}{c}\text { alt } \\
\text { (meter } \\
\text { a.s.l.) }\end{array}$ & $\begin{array}{c}\text { number } \\
\text { of taxa }\end{array}$ & $\begin{array}{c}\text { Sørensen } \\
\text { index }\end{array}$ \\
\hline $\begin{array}{l}\text { Central Park of Eger } \\
\text { (present study) }\end{array}$ & 14 & 0 & $155-165$ & 59 & 1 \\
\hline $\begin{array}{l}\text { Botanical Garden of } \\
\text { EKU, Eger (Hungary) } \\
\text { (Szűcs et al. 2017b) }\end{array}$ & 1 & 1.3 & 230 & 46 & 0.590 \\
\hline $\begin{array}{l}\text { Mátrai Sanatorium, } \\
\text { Mátraháza (Hungary) } \\
\text { (Szűcs et al. 2018) }\end{array}$ & 14 & 30.4 & $650-700$ & 65 & 0.564 \\
\hline $\begin{array}{c}\text { Horka forest park, } \\
\text { Velky Krtís, (Slovakia) } \\
\text { (Mišíková et al. 2007) }\end{array}$ & 1500 & 83 & 210 & 37 & 0.541 \\
\hline $\begin{array}{l}\text { Vrana Park, Sofia } \\
\text { (Bulgaria) } \\
\text { (Gospodinov et al. } \\
\text { 2018) }\end{array}$ & 99.3 & 623 & 560 & 68 & 0.488 \\
\hline $\begin{array}{c}\text { Pohulyanka forest } \\
\text { park, Lviv, (Ukraine) } \\
\text { (Mamchur et al. 2018) }\end{array}$ & 129 & 343 & $340-370$ & 108 & 0.455 \\
\hline $\begin{array}{c}\text { Exp. and Teaching } \\
\text { Garden, Łódź, } \\
\text { (Poland) (Wolski et al. } \\
\text { 2012) }\end{array}$ & 1 & 435 & 225 & 42 & 0.415 \\
\hline
\end{tabular}

\section{Conservation status}

Five taxa belong to the near threatened (NT) category according to the Hungarian Red List (Papp et al. 2010): Brachythecium glareosum, Cirriphyllum piliferum, Eucladium verticillatum, Orthotrichum obtusifolium and Orthotrichum pumilum. Another eight species belong to least concern attention (LC-att), viz. Bryoerythrophyllum recurvirostrum, Didymodon rigidulus, Homalia trichomanoides, Hygroamblystegium varium, Orthotrichum cupulatum, Orthotrichum striatum, Syntrichia papillosa, and Syntrichia virescens.

Some indicator mosses (species which by their presence indicate a higher conservation value of the habitat) also occur in the park, for example Cirriphyllum piliferum, Eucladium verticillatum, Homalia trichomanoides, Hygroamblystegium varium, 
Orthotrichum cupulatum, O. obtusifolium, O. pumilum, O. speciosum, O. striatum, and Syntrichia papillosa.

\section{Life strategies}

There is a remarkable difference between central park of Eger and other local or regional habitats (Table 1) concerning the percentage of species in each of the life strategy categories (Dierßen 2001). Central park of Eger is more abundant in colonists and pioneer colonists, and less abundant in long-lived shuttle, perennial, and competitive perennial species, compared to the other habitats. None of the bryophytes in the Central park of Eger belong to the ephemeral colonist and fugitive categories (Figure 3).

A possible explanation for the above phenomenon is that abundant bare soil surface is available for the bryophytes, but disturbed substrates are very rare in the studied area.

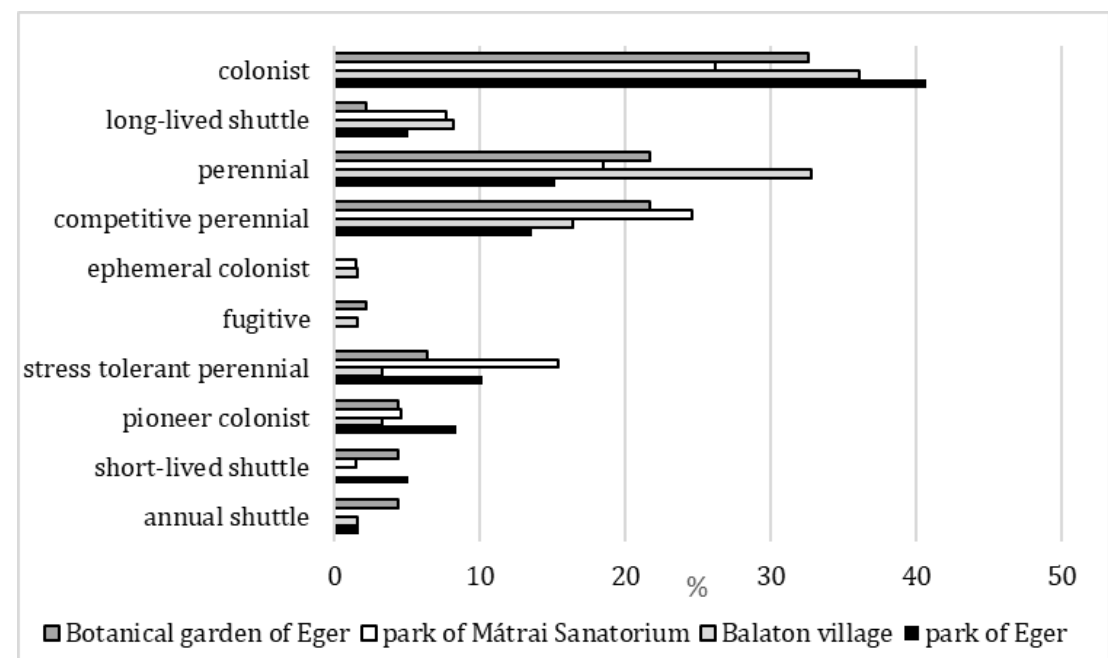

Figure 3. Comparison of the life strategies of bryophytes in Botanical Garden of Eger (Szűcs et al. 2017b), park of Mátrai Sanatorium (Mátraháza) (Szűcs et al. 2018), Balaton village (Zsólyom and Szűcs 2018) and central park of Eger (present study). 


\section{CONCLUSIONS}

The central park of Eger has a remarkable bryophyte diversity, which is of comparable magnitude to local, regional places and central east european urban parks in accordance with its size. The high number of indicator mosses shows a high level of conservation value of the park.

The rich bryophyte flora partly can be expained by the history of the different habitats, the abundance of old and varied deciduous trees and the proximity of Eger creek and the municipal thermal spa.

Acknowledgement - The authors would like to express their gratitude to Peter Erzberger and Andrea Sass-Gyarmati for their useful comments. The authors would like to thank Tamás Pócs for the identification of Eucladium verticillatum. The first author's research was supported by the grant EFOP-3.6.1-16-201600001 ("Complex improvement of research capacities and services at Eszterházy Károly University"). Special thanks to András Vojtkó and András Schmotzer for their help with literature.

\section{REFERENCES}

DIERßEN, K. (2001). Distribution, ecological amplitude and phytosociological characterization of European bryophytes. Bryophytorum Bibliotheca 56: 1289.

DöVÉNYI, Z. (ed.) (2010). Magyarország kistájainak katasztere. MTA Földrajztudományi Kutatóintézet, Budapest, 824 pp.

FUDALI, E. (2006). Influence of city on the floristical and ecological diversity of bryophytes in parks and cemeteries. Biodiversity. Research and conservation 12: 131-137.

GodovičovÁ, K. \& MišíKovÁ, K. (2017). Epifytické machorasty urbánneho prostredia Bratislavy (Epiphytic bryophytes in the urban environment of Bratislava). Bryonora 59: 44-57.

Goffinet, B. \& Shaw, A.J. (eds.) (2009). Bryophyte biology. Cambridge University Press, Cambridge, 565 pp.

GomolU, I. \& ȘTEFĂNUŢ, S. (2008). Lichen and bryophytes as bioindicator of air pollution. In: Cracium, I. (ed.) Species monitoring in the central parks of Bucharest. Universitatea din București, Bucharest, pp. 14-25.

Gospodinov, G., Lambevska-Hristova, A., Natcheva, R. \& Gyosheva, M. (2018). Vrana Park - a neglected site for bryophyte and fungal diversity in Sofia city. Phytologia Balcanica 24(3): 323-329.

Herzegné SzÉKelY, A. (2010). Az Érsekkert története. In: ReNn, O. (ed.): Egri séták nemcsak Egrieknek I. Egri Lokálpatrióta Egylet, Eger, pp. 133-147. 
Hill, M.O., Bell, N., Bruggeman-Nannaenga, M.A., Brugues, M., Cano, M.J., Enroth, J., Flatberg, K.I., Frahm, J.-P., Gallego, M.T., Garilleti, R., Guerra, J., Hedenäs, L., Holyoak, D.T., Hyvönen, J., Ignatov, M.S., LaRa, F., MazimpaKa, V., MuÑOZ, J. \& SöDERSTRÖM, L. (2006). An annotated checklist of the mosses of Europe and Macaronesia. Journal of Bryology 28: 198-267. https://doi.org/10.1179/174328206x119998

Király, G., BAlogh, L., Barina, Z., BARTha, D., BAUER, N., Bodonczi, L., DANCZA, I., FARKAS, S., Galambos, I., Gulyás, G., Molnár, V. A., Nagy, J., Pifkó, D., Schmotzer, A., Somlyai, L., Szmorad, F., VidéKI, R., VojtKó, A., \& ZólYomi, Sz. (2003). A magyarországi flóratérképezés módszertani alapjai. Flora Pannonica 1: 3-20.

KIRÁLY, G. (ed.) (2009). Új magyar füvészkönyv (Magyarország hajtásos növényei, határozókulcsok). Aggteleki Nemzeti Park Igazgatóság, Jósvafő, 616 pp.

Király, G., Baráth, K., BAuer, N., Erzberger, P., PApp, B., Szû́cs, P., Veres, Sz. \& Barina, Z. (2019). Taxonomical and chorological notes 8 (85-93). Studia botanica hungarica 50(1): 241-252. https://doi.org/10.17110/StudBot.2019.50.1.241

Mamchur, Z., Drach, Y. \& DANYlKiv, I. (2018). Bryoflora of the "Pohulyanka" forest park (Lviv city) I. Changes in taxonomic composition under anthropogenic transformation. Studia Biologica 12(1): 99-112. https://doi.org/10.30970/sbi.1201.542

Miší́KovÁ, K., MišIK, M. \& KubinSKÁ, A. (2007). Bryophytes of the forest park Hôrka (Vel'ký Krtíš town, Slovakia). Acta Botanica Universitatis Comenianae 43: 9-13.

NAGY, Z., MAJLÁTh, I., MolnÁR, M. \& ERZBERGER, P. (2016). A martonvásári kastélypark mohaflórája. (Bryofloristical study in the Brunszvik manor park in Martonvásár, Hungary). Kitaibelia 21(2): 198-206. https://doi.org/10.17542/kit.21.198

Nielsen, A.B., Bosch, M., Maruthaveeran, S. \& Bosch, C.K. (2014). Species richness in urban parks and its drivers: A review of empirical evidence. Urban Ecosystems 17(1): 305-327. https://doi.org/10.1007/s11252-013-0316-1

Papp, B., Erzberger, P., Ódor, P., Hock, Zs., SzövÉnyi, P., Szurdoki, E. \& Tóth, Z. (2010). Updated checklist and red list of Hungarian bryophytes. Studia botanica hungarica 41: 31-59.

SøRENSEn, T. (1948). A method of establishing groups of equal amplitude in plant sociology based on similarity of species content. Kongelige Dansk e Videnskabernes Selskab. Biologiske Skrifter 4: 1-34.

Söderström, L., Hagborg, A., von Konrat, M., Bartholomew-Began, S., Bell, D., Briscoe, L., Brown, E., Cargill, D.C., Costa, D.P., Crandall-Stotler, B.J., Cooper, E.D., Dauphin, G., Engel, J.J., FeldberG, K., Glenny, D., Gradstein, S.R., He, X., HeinrichS, J., Hentschel, J., IlKiu-Borges, A.L., Katagiri, T., KonstantinOva, N.A., LaRraín, J., LONG, D.G., Nebel, M., Pócs, T., Puche, F., Reiner-Drehwald, E., Renner, M.A.M., SassGyarmati, A., Schäfer-Verwimp, A., Moragues, J.G.S., Stotler, R.E., Sukkharak, P., Thiers, B.M., URibe, J., VáŇA, J., Villarreal, J.C., Wigginton, M., Zhang, L. \& Zhu, R.-L. (2016). World checklist of hornworts and liverworts. PhytoKeys 59: 1-828. https://doi.org/10.3897/phytokeys.59.6261

SugÁR, I. (1983). Eger Gyógyvizei és fürdői. Eger Város Tanácsa V. B. Műszaki Osztálya és a Heves megyei Idegenforgalmi Hivatal kiadása, Eger, 441 pp. 
Szepesfalvi, J. (1940). Die Moosflora der Umgebung von Budapest und des Pilisgebirges I. Annales historico-naturales Musei nationalis hungarici 33: 1104.

SzEPESFALVI, J. (1941). Die Moosflora der Umgebung von Budapest und des Pilisgebirges II. Annales historico-naturales Musei nationalis hungarici 34: 171.

SzePeSfalvi, J. (1942). Die Moosflora der Umgebung von Budapest und des Pilisgebirges III. Annales historico-naturales Musei nationalis hungarici 35: 172.

SzÛ́cS, P. (2015). Kindbergia praelonga (Hedw.) Ochyra Sopron város mohaflórájában. Kitaibelia 20(2): 305.

SzÚCS, P., BöRCSÖK, Z. \& KÁMÁN, O. (2014). A Riccia glauca L. és a Riccia sorocarpa Bisch. előfordulása Barcs belterületén. Kitaibelia 19(2): 365.

SzÛ́CS, P., PÉnZES-KónYA, E. \& Hofmann, T. (2017a). The bryophyte flora of the village of Almásfüzitő, a former industrial settlement in NW-Hungary. Cryptogamie, Bryologie 38(2): 153-170. https://doi.org/10.7872/cryb/v38.iss2.2017.153

SZǓCS, P., TÁbORSKÁ, J., BARANYI, G. \& PÉNZES-KóNYA, E. (2017b). Short-term changes in the bryophyte flora in the Botanical Garden of Eszterházy Károly University (Eger, NE Hungary). Acta Biologica Plantarum Agriensis 5(2): 52-60. https://doi.org/10.21406/abpa.2017.5.2.52

SzÚCS, P., BARANYI, G. \& FInTHA, G. (2018). The bryophyte flora of the park of Mátrai Gyógyintézet Sanatorium (NE Hungary). Acta Biologica Plantarum Agriensis 6: 123-132. https://doi.org/10.21406/abpa.2018.6.123

Wolski, G.J., STEFANIAK, A. \& KowAlKiEWicZ, B. (2012). Bryophytes of the experimental and teaching garden of the faculty of biology and environmental protection, University of Łódź (Poland). Ukrainian Botanical Journal 69(4): 519-529.

ZsóLYom, D. \& SzÛ́CS, P. (2018). Balaton település (Heves megye) mohaflórája. (The bryophyte flora of Balaton village (Heves county, Hungary)). Botanikai Közlemények 105(2): 231-242.

https://doi.org/10.17716/BotKozlem.2018.105.2.231

(submitted: 10.12.2019, accepted: 27.04.2020) 


\section{APPENDIX}

\section{Site details}

1. soil, artifical stone, bark of trees $(04.12 .2018,01.08 .2019,02.03 .2020)$ $\mathrm{N} 47^{\circ} 53^{\prime} 53^{\prime \prime} \mathrm{E} 20^{\circ} 22^{\prime} 46^{\prime \prime}$

2. rock in stream water (14.06.2019) N47 $53^{\prime} 52^{\prime \prime}$ E20 $22^{\prime} 52^{\prime \prime}$

3. wall of the stream bank, soil $\left(14.06 .2019,03.07 .2019\right.$.) N47 $53^{\prime} 49^{\prime \prime} \mathrm{E} 20^{\circ} 22^{\prime} 54^{\prime \prime}$

4. mown lawn, soil (13.03.2019., 03.07.2019) N4753'50" E20 22'50"

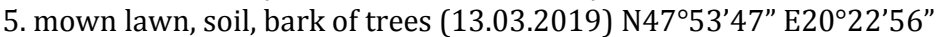

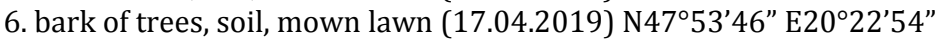

7. mown lawn, bark of trees, concrete (11.03.2019) N4753'41" E20 $22^{\prime} 54^{\prime \prime}$

8. artifical stone, soil, concrete (11.03.2019) N47 $53^{\prime} 45^{\prime \prime}$ E20 $22^{\circ} 50^{\prime \prime}$

9. soil (11.03.2019) N4753'40" E20 22'52"

10. stone fence, soil (11.03.2019) N47 ${ }^{\circ} 53^{\prime} 44^{\prime \prime} \mathrm{E} 20^{\circ} 22^{\prime} 44^{\prime \prime}$

11. artifical lake (14.06.2019) N47 $53^{\prime} 49^{\prime \prime}$ E20 $22^{\prime} 45^{\prime \prime}$

12. mown lawn, concrete, soil (13.03.2019) N475' $51^{\prime \prime}$ E20 $22^{\prime} 40^{\prime \prime}$

13. artifical stone wall $(14.04 .2019,14.06 .2019)$ N47 $53^{\prime} 48^{\prime \prime}$ E $20^{\circ} 22^{\prime} 44^{\prime \prime}$ 